\title{
Murray N. Rothbard's Paleolibertarianism. In Search for a Political Success during the Republican Party Presidential Primaries 1992
}

\section{El paleolibertarismo de Murray N. Rothbard. En busca de un éxito político durante las primarias presidenciales del Partido Republicano de 1992}

\author{
Marcin CHMIELOWSKI \\ Freedom and Entrepreneurship Foundation, Poland \\ chmielowski@fundacjawip.org
}

Recibido: 06/10/2015

Aceptado: 03/07/2016

\begin{abstract}
Any evaluation of paleolibertarianism must be twofold. As it has been touched upon at the beginning of this article, it would be a good idea to view paleolibertarianism from two angles. As a political proposition, related to the "here and now" in which it came to be, as well as a theory of its own, the way it was expressed by Rothbard and Rockwell, it contributed something new to the already diverse tree of libertarianism. The first assessment must be mixed, partly negative.

It is not so straightforward to assess paleolibertarianism as an idea. Its this potential was never squandered, thanks to the continued activities of the Mises Institute in Auburn, Alabama. Rothbard's work is being continued. And for the libertarian movement as a whole, it is advantageous that its individual parts clearly indicate the similarities and difference between them. Libertarianism is a young ideology, and an internal debate, and Rothbard's legacy invites one, can only serve to further the cause of liberty.

Keywords: Paleolibertarianism, Murray N. Rothbard, Rothbard-Rockewll Report.
\end{abstract}

\section{Resumen}

Toda evaluación del paleolibertarismo debe cubrir dos vertientes. Tal y como se menciona al inicio de este artículo, sería una buena idea contemplar el paleoliber- 
tarismo desde dos ángulos diferentes: como una propuesta política, relativa al "aquí y ahora"en el que surgió, y también como una teoría propiamente dicha, según fue formulada por Rothbard y Rockwell, que aportó algo nuevo al ya plural campo del libertarismo. La primera valoración puede ser ambivalente en tanto que parcialmente negativa.

No es tan evidente valorar el paleolibertarismo como una idea. Su potencial nunca fue obviado gracias a las continuas actividades del Instituto Mises en Auburn, Alabama, en el que se continúa el trabajo de Rothbard. Y para el movimiento libertario en su conjunto, resulta de provecho que sus vertientes particulares indiquen claramente las similitudes y diferencias existentes entre ellas. El libertarismo es una ideología joven y el debate interno al que invita el legado de Rothbard sólo puede servir para promover la causa de la libertad.

Palabras clave: Paleolibertarismo, Murray N. Rothbard, Informe Rothbard-Rockwell.

There exists a common conviction that Murray Rothbard never revised his beliefs. It is partially true: in principal issues, such as the nature of the state or the foundations of the economic scene he was indeed a man of principle. During the course of life he did however change his mind on politically technical ideas that were secondary to his ideological foundations. There is nothing wrong with that - to the contrary, in fact. The political reality that surrounded Rothbard was itself subject to change, therefore he also had to adjust his message. This paper concerns one of the periods (the final one) during which Rothbard expressed consistent and well-argued views on issues secondary to the problem of the nature of the state. The period of "Rothbardian paleolibertarianism" that occupied the five final years of his life $(1990-1995)$ is a source for many interesting thoughts, which undoubtedly warrant analysis.

A few initial remarks: this paper was written by a political scientist, not an economist. This changes the balance of these considerations of Rothbard's legacy from purely economic to strictly political, specifically one of systematic reflection on the theory and practice of formal structures of power. The following considerations center around Rothbard's theory of the state, its criticism and attempts at remedying a state of affairs he thought detrimental. Paleolibertarianism is one such proposition for alleviating the condition noted by Rothbard. It is a bit of a distorted idea, as it is in stark contrast to the revolutionary nature of libertarianism. Libertarianism's primary goal is a complete alteration of contemporary relations between the state and the citizen, usually, though not always, through the abolition of the state understood as territorial monopoly on violence. The distortion of this idea consists in the fact that Rothbard's paleolibertarianism, as a reflection, is a fully independent idea, but in the solutions it offers it is a full-fledged political proposition, an attempt at forging 
alliances with forces with which it is possible to communicate about at least some elements of a political program. For this reason, Rothbard's paleolibertarianism ought to be considered on two levels. As another "brand" of libertarianism, a theoretical proposition, as well as an attempt playing libertarianism as a political position in the broader context of American politics of the first half of the 1990s. In this sense, Rothbard's paleolibertarianism is a proposed method of changing the actual political sphere, as far as it is possible, of course. These two realities, the theoretical one, stemming from considerations of the activities of the libertarian movement in the US, which Rothbard was a veteran of, and the practical one, concerned with public and political libertarian activism, are, of course deeply related.

\section{Freedom strategy}

In spite of what his critics claim, Rothbard was not an out-of-touch theoretician. Not only did he closely follow the whole of domestic politics and the most important events of foreign politics, which is attested by the ample body of journalistic work he left behind, he was also and active part of public life, even a politician. This could seem contrary to his consistent a priori criticism of the state, but is fully in line with his beliefs. In his classic polemic with Konkin on the goal, methods and organization of the libertarian movement, Rothbard wrote:

Why should we cut ourselves off from this necessary and vital step of doing the repealing? Of course if one believes with Bob LeFevre that it is equally immoral to repeal as to impose the draft, then the repeal of anything is out of the question. But I will shout hosannahs for any repeal of statism [highlighted by the author], and do not concern myself with the "coercion" of those who'd like to keep the draft and are deprived of it. ${ }^{1}$

Although this quote concerns a certain very specific issue (military conscription), it did relate to the whole of pro-libertarian activities. In Rothbard's view, as evidenced by his entire biography as an activist, libertarian ideas must be pushed into the intellectual and medial discourse, but also into politics, as far as it is possible. This means that, in light of obvious political weakness of the libertarian circles, alliances are necessary. Of course, Rothbard tried to find such alliances, but not in all situations, because he considered it means to an end, and not a condition in itself. Still, when he thought an alliance realize a proposed libertarian solution, he would attempt to find someone that could help him.

\footnotetext{
${ }^{1}$ M. N. Rothbard, Konkin on Libertarian Strategy, retrieved, 20 February 2015 from: http://www. anthonyflood.com/rothbardkonkin.htm.
} 
At this point, a question presents itself: how far can one go with such alliances? In other words, Rothbard had to decide how to act. In order to make that decision, he used terminology and ideas originating in Leninism. In his 1961 memo addressed to F.A. Harper and George Resch, Rothbard considers tactical possibilities available to the libertarian movement. He sees libertarians as revolutionaries, but not in the sense that they would attempt to take control of the state by force, rather they are disseminators of revolutionary ideas, trying to shake the sphere of concepts:

I am here Rusing the shock term „revolution” not In the sense of violent, or even nonviolent revolution against the State. I mean by "revolution" the effecting of an ideological revolution in the framework of ideas held by the bulk of our fellow man. We are, in this sense, revolutionaries - for we are offering the public a radical change in their doctrinal views and we are offering it from a firm and consistent base of principle that we are trying to spread among the public. ${ }^{2}$

Rothbard thought that libertarians ought not to limit themselves to theoretical considerations on libertarianism, but also should popularize libertarianism and ideas for freedom. ${ }^{3}$ In order to do that effectively, they would have two be wary of two extremes: "left-wing opportunism" and "right-wing sectarianism". ${ }^{4}$ These terms were used in Rothbard's well-known program work, For New Liberty: The Libertarian Manifesto. ${ }^{5}$

The "sectarian strategy" is, according to Rothbard, treating any collaboration with anyone from outside the "sect" as treason. Such approach is, in Rothbard's view undoubtedly noble, but almost always ineffective. ${ }^{6}$

The "opportunistic strategy" consists in being willing to collaborate with anyone and thereby realizing at least a part of one's goals, but at the cost of losing their completeness for a sort of "realism".?

How is a libertarian as and individual and the libertarian movement as a whole supposed to navigate between these two extremes, which threaten to make their adherents into caricatures of themselves, one funny ("sect"), and one sad ("opportunism")? Rothbard thought that an optimal solution would be to ensure the hard core

\footnotetext{
${ }^{2}$ Idem, "What Is to Be Done? Rothbard's Confidential Memorandum to the Volker Fund", in D. Gordon (ed.), Strictly confidential: The Private Volker Fund Memos of Murray N. Rothbard, Auburn, Ludwig von Mises Institute, 2010, p. 8.

${ }^{3}$ Ibidem, pp. 8-9.

${ }^{4}$ Lenin's writing mentioned an oppostite division: left-wing sectarianism and right-wing opportunism. Rothbard consciously reversed these terms to fit libertarians.

${ }^{5}$ Idem, For a New Liberty. The Libertarian Manifesto, Auburn, Ludwig von Mises Institute, 2006, p. 376.

${ }^{6}$ Idem, What Is to Be Done? ..., op. cit., pp. 8-9.

${ }^{7}$ Ibidem, p. 9.
} 
of the movement stays at top intellectual level, to try then to expand the size of that core, to popularize libertarianism and to engage in pro-libertarian activities:

To restate my view of the proper strategy: we must, first and foremost, nourish and increase the hard core; we must, then, try to diffuse and advance principles and action as far as possible in the direction of hardcore doctrines. To abandon the hard core liquidationist; to abandon all hardcore leverage upon others is to remain sterile and ineffective. We must combine the two elements; we must, in short, nourish and develop a hard core, which will then permeate and exert leverage upon others. ${ }^{8}$

The turns of Rothbard's fate at the time when he tried to forge libertarians into a pressure group capable of influencing the political sphere to reflect their postulates, as a political party or as group allied with another political association can be interpreted as an attempt to avoid the two the two extremes mentioned above.

\section{Tactical alliances}

In Rothbard's public activities, which are separate from his academic work, there are four distinct periods:

1. The early years, Rothbard's affiliation with the Bastiat Circle (1953-1959) and the work for the Volker Fund (1951 - 1962), so a period from the 1940s to mid 1960s.

2. The period of collaboration with the New Left, which begins in the mid 1960s. The end of this period is marked by the foundation of the Libertarian Party in 1971.

3. The period of activism within the Libertarian Party, so from 1971 to 1990.

4. Paleolibertarianism, so an attempt at collaboration with a part of the American Right, from 1990 to 1995.

Of course, such compartmentalization cannot be perfect, due, among others, to the sheer number of institutions Rothbard worked with. In his foreword to Strictly confidential: The Private Volker Fund Memos of Murray N. Rothbard, Brian Doherty enumerates the following organizations that "Mr. Libertarian" was a member (or indeed the spiritus movens) of: Foundation for Economic Education, Volker Fund, Institute for Humane Studies, Libertarian Party, Center for Libertarian Studies, Cato Institute, Ludwig von Mises Institute. ${ }^{9}$ Additionally, there was Rothbard's enthusiastic journalistic activities. Thus, exact dating of various phases of Rothbard's activ-

\footnotetext{
${ }^{8}$ Ibidem, p. 12

${ }^{9}$ D. Brian, "Foreword", in: Ibidem, s. ix.
} 
ism is made difficult. It is however not impossible, as long as we accept as the key certain dominant features from each period.

And so, in the early years, at the time when he worked for the Volker Foundation and was active in the Bastiat Circle, Rothbard tended towards increasing affiliation with the old American Right, a political movement contesting the state's interference in the lives of the citizens, anti-interventionist in nature and fairly traditional in its outlook on social issues. A movement, what is key, weakening from year to year in light of the continued assault of the aggressive and expansionist majority of the Republican Party, which was taking over the Old Right's territory, even in strictly biological sense, as the older Old Right affiliates were simply dying out. ${ }^{10}$

In the 1960s, which in the US were marked by the Vietnam War and the emergence of counter-cultural movements, Rothbard attempted to communicate with the New Left, which, compared to the Old Right was a very exotic ideological environment, in opposing the war and a quite honest dislike for the American state. And that was a common ground with Rothbard, which led to the creation of Left and Right. In its first issue, Rothbard wrote in an editorial:

Conservatism is a dying remnant of the ancien regime of the pre- industrial era, and, as such, it has no future. In its contemporary American form, the recent Conservative Revival embodied the death throes of an ineluctably moribund, Fundamentalist, rural, small-town, white Anglo-Saxon America. ${ }^{11}$

Rothbard attended many anti-government gatherings, which were decidedly leftist in nature. Such an ephemeral attempt at forging an alliance can hardly be considered fruitful. Later, Rothbard would distance himself from his activities during this period of his life, which is demonstrated in a 1972 interview with the New Banner:

NEW BANNER: Do you see any wisdom in anarcho-capitalists allying with today's New Left?

ROTHBARD: There is no New Left now. The New Left is really finished — there isn't any such animal anymore. One of the reasons that I liked the New Left in the old days, in the middle-60's, was that there were a lot of libertarian elements in the New Left. Not only was there opposition to the war and the draft, but also opposition to bureaucracy, central government and so forth. But all that seems to have dropped out. There is really nothing going on in the New Left now at all. ${ }^{12}$

\footnotetext{
${ }^{10}$ A description of the Old Right and Rothbard's view on the causes of its demise can be found in his book: The Betrayal of the American Right (Auburn, 2007).

${ }^{11}$ M. N. Rothbard, "Left and Right: The Prospects for Liberty", in Left and Right, no 1, Spring 1965.

${ }^{12}$ The New Banner Interview with Murray N. Rothbard, retrieved 20 February 2015 from: http://mises.
} 
This sentiment is elaborated upon in a farewell-to-the-New-Left article by Rothbard:

The original idea in allying ourselves with the New Left was to work with a new generation permeated with strong libertarian elements. Now that the New Left has died, and its genuine libertarian elements have disappeared, objective conditions require that we make a tactical shift away from the current Left. Instead, too many of our young East Coast libertarians have done just the opposite of Lenin's strategic advice: they cling as a vital principle to the mere tactic of alliance with the Left; and they abandon their original principles (free-markets, private property rights) that led them to becoming libertarians, and therefore into making tactical alliances in the first place... They have tragically allowed the means to become an end, and the end to become a mere means. ${ }^{13}$

Another initiative was the Libertarian Party, a self-contained political entity, which had the potential at delivering at least some libertarian ideas to DC. Rothbard was affiliated with the Party from the very begging, though he was often critical of it. In the New Banner interview quoted above, when Rothbard was asked about the purpose behind a libertarian party, he said:

I think if there were a libertarian party - and I don't want to make it seem as if this is a realistic thing at this time - if there ever were a strong libertarian party it could do several things. Tactically, we could have a balance of power. Even better as an educational weapon. If we had ten guys in Congress, let's say, each of whom are constantly agitating for libertarian purposes — voting against the budget, etc., I think it would be very useful. ${ }^{14}$

Further in the interview, Rothbard admitted that using political action as a tool for initiating pro-libertarian changes is matter of tactics, which illustrates his approach to politics as such: politics is merely a useful tool for implementing ideas. But that does not mean it is the only one, or even the best one. This is simply unknown, as the future cannot be accurately foreseen. This tactical approach to the politics of the Libertarian Party can also be found in Rothbard's article on the 1980 presidential campaign, when the Party's candidate was Edward Clark, with David Koch as his running mate. In his Albany speech (as printed in The Libertarian Forum) Mr. Libertarian said:

org/library/new-banner-interview-murray-n-rothbard-0.

${ }^{13}$ M. N. Rothbard, "Farewell to the Left", The Libertarian Forum, vol. II, issue 9, May $1^{\text {st }} 1970$.

${ }^{14}$ The New Banner Interview..., op. cit. 
The first and most important task of a Libertarian Presidential campaign is to cleave to, and be proud of, libertarian principle throughout the campaign. Second, we must select the most important political issues of the day on which to campaign. ${ }^{15}$

Rothbard's collaboration with the Libertarian Party lasted until the early 1990s. It was then that he decided to once again change his tactics and try to promote libertarian ideas differently than before, with different allies, but still within the sphere of politics.

\section{The Rothbard - Rockwell Report and its paleolibertarian message}

April of 1990 saw the publication of the first issue of a new magazine edited by Mr. Libertarian: the Rothbard - Rockwell Report. And so, like Left and Right a decade earlier was meant to be a bridge to the New Left, the Rothbard - Rockwell Report would form a similar bridge to a dissimilar ally in the fight for liberty.

First however, Rothbard left the Libertarian Party. In article titled "Why the Report?" from April 1990, written together with Lew Rockwell, Rothbard expressed his doubts about the libertarian movement in the US, and particularly about the Libertarian Party. He stated that, judging by both the quality and the number of libertarian publications, the movement, rather than developing, was shrinking and becoming ever more intellectually void. Most of its activists were aging hippies, often incapable of supporting themselves. Thus, as he claimed, Rothbard decided to leave libertarianism. He no longer wanted to use the that term to label himself. Instead, he chose the neologism "paleolibertarianism", which is perhaps best defined by the following excerpt from the article:

The two of us are hard-core libertarians, but we have also long been "paleos" - men devoted to bourgeois values and culture and staunch opponents of the nihilist "counter-culture". ${ }^{16}$

This no-nonsense promise of a new direction for libertarianism was of course taken further in Rothbard's subsequent publications and activities. A criticism of his former party colleagues and libertarians in general came in the very next issue of the Rothbard - Rockwell Report. The article titled "Why Paleo?" was an uncompromising ${ }^{17}$ assault on American pro-liberty activism, which Rothbard thought to be in a miserable state. Mr. Libertarian describes such activists as out-of-touch people who are unable to notice even such political breakthroughs as the dissolution of the

\footnotetext{
${ }^{15}$ M. N. Rothbard, "The Presidential Campaign: The Need For Radicalism”, The Libertarian Forum, 2.

${ }^{16}$ M. N. Rothbard, L. Rockwell, "Why the Report?", Rothbard-Rockwell Report, April 1990 p. 2.

${ }^{17}$ Even by Rothbard's standards, who at times spoke in very harsh terms.
} 
Eastern Bloc, and instead live in a world of their own, failing to re-think their tactics, which have become a necessity for libertarianism. ${ }^{18} \mathrm{~A}$ "modal libertarian" is usually an aging IT engineer without permanent employment, and expert in science-fiction and libertarian writings who has no other knowledge, and, to make matters worse, is unwilling to acquire any. Fascinated with Ayn Rand, ${ }^{19}$ whose works, nevertheless, he interprets in a fairly shallow manner - as his own rebellion against all public institutions. His mistrust of the state is not based in any reflection or understanding of the state's nature (which Rothbard invariably interpreted as one of a gang that keeps violating the non-aggression principle) but is only a puerile revolt against all authority figures. Such a revolt fails to comprehend that some such figures (those whom Hans - Hermann Hoppe would later refer to as the "natural elite", which Rothbard was not able to fully articulate in the early 1990s) are simply important and necessary for the correct functioning of individuals in society. But what a "modal libertarian" opposes the most are the bourgeois and Christianity. ${ }^{20}$

This bleak outlook, Rothbard says, evidences that throughout the previous twenty years (1970-1990), the libertarian movement in the US did not develop at all, which can best be seen in the Libertarian Party itself, as it is the most formalized of libertarian institutions, and thus the most transparent one. Those who were unemployed students during the 1970s were still unemployed in the 1990s, but were now forty years old, not twenty. Nothing else changed in their lives. If they hadn't been developing as individuals, the institutions they make up couldn't have developed either. Therefore, it was Rothbard's view that it had become necessary to leave the libertarian movement, convincing those of its members who would label themselves paleolibertarian to come along and create with them a common ground for communication with members of the re-emerging Old Right. They, just like Rothbard, couldn't accept the libertarian movement in its current shape, and considered it to be nihilistic and incapable of understanding the changes brought about by the closure of the bi-polar model of global politics. ${ }^{21}$

\section{The paleo-alliance}

A this stage of the analysis of Rothbard's plan for cooperation with paleoconservatives, we come upon the following elements: first, the tactical approach to allies

\footnotetext{
${ }^{18}$ M. N. Rothbard,"Why Paleo?", Rothbard-Rockwell Report, May 1990, p. 1.

${ }^{19}$ The animosity between Rothbard and Rand was no mystery at the time. They accused each other of many things, with Rothbard claiming that it was Rand's fault that so many hippies joined the libertarian movement, but taking Rand's opinion on counter-cultural movements into account, including her intent dislike of the hippies, it is hard to blame Rand for the fact the libertarian circles included many people with views similar to those of the hippies.

${ }^{20}$ Ibidem, pp. 3-5.

${ }^{21}$ Ibidem, p. 5.
} 
and alliances; second, the consent to, for the time being, put his ideas into practice only partially, hoping to realize them fully at an unspecified point in the future; third, a very negative opinion of American libertarians, who are thought incapable to of acting on their beliefs. In Rothbard's view, it is possible to be both a permissive libertarian as well as one that values the bourgeoisie virtues, or the traditional model of life. These elements add up to need for a new ally, whose worldview is partially convergent with Rothbard's. That ally turned out to be the paleoconservatives. Or, in other words, the Old Right.

Paleoconservatives were a faction within the Republican Party that oppose foreign interventionism, it was moderately (when compared to libertarians) pro-market and, as well as patriotic and socially conservative. Another faction that paleolibertarians recognized (strictly for the purposes of their political writing) within the Grand Old Party were the neoconservatives. These were supporters of a powerful interventionist state, themselves a reincarnation of the Rockefeller Republicans. ${ }^{22}$ The solution that would allow paleolibertarians to circle around the neocons and emerge beyond the exhausted paradigm of previous libertarian activity was to be the "paleo-alliance", so one between the paleolibertarians and paleoconservatives. A joint conference of these two circles occurred as early as 1989. Those that met under the common banner "Beyond the Welfare - Warfare State. Setting the agenda for 1990's" ${ }^{23}$ were, among others: Murray Rothbard, Lew Rockwell, Joseph Sorban, ${ }^{24}$ Mel Bradford, ${ }^{25}$ Thomas Flemming ${ }^{26}$ and Paul Gottfried. ${ }^{27}$ Evidently, then, it was a meeting more of writers, commentators and academics, but of politicians as well, to a lesser extent. The conference did manage to spark cooperation between the two groups, as the following year saw the creation of the John Randolph Club, the purpose of which was to work towards strengthening the alliance. ${ }^{28}$ Rothbard's coverage of the Club's first session serves as a record of the attempts to compromise with the paleoconservatives. In the article titled "The New Fusionism" published in January 1991 Rothbard relates the subjects discussed by the participants. Furthermore, he stresses that the meeting was held as a conference not in order to criticize the beliefs of others, but to help the participants identify the views shared by the other side. The topics included: foreign policy, civil rights, immigration, and the socalled "New Puritanism:" the question of jurisdiction and its territorial character. Of

\footnotetext{
${ }^{22}$ It is not at this point critically important if such a faction layout could indeed be found within in the $\mathrm{GOP}$ at the time. What matters is that this was the way Rothbard and his paleolibertarian followers saw it.

${ }^{23}$ L. Rockwell, “A New Right”, Rothbard-Rockwell Report, April 1990, p. 11.

${ }^{24}$ Journalist and political writer; he wrote to - among others - the National Rewiev.

${ }^{25}$ Profesor of literature, literacy critic.

${ }^{26}$ Catholic activist, writer.

${ }^{27}$ Historic of ideas, political philosopher, writer.

${ }^{28}$ L. Rockwell, “A New Right”, Rothbard-Rockwell Report, January 1991, pp. 6-9.
} 
course, the participants agreed on some points and disagreed on others. Both sides argued for a non-interventionist foreign policy. The question of civil rights did not cause any controversy either, though some difference of opinion came to view there. What divided the room was the issue of immigration. The paleolibertarians favored the idea of open borders and the paleoconservatives were against it, citing concerns for the continuity of national heritage. The final panel on legal obligations and a possible exemption from a given legal system (and adopting a different on, due to e. g. religious reasons) did not cause any disagreement. What was debated was the perception of community, which, for both parties, could very well serve to regulate law on its territory. The paleolibertarians saw it as voluntary agreements between property owners, and the paleoconservatives viewed it more as a governing body such as a local government. ${ }^{29}$

Rothbard's article "Right-Wing Populism: a Strategy for the Paleo Movement" published after the conference served as an elaboration of the subjects that the conference touched upon, it also provided a broader background that was intended to validate the actions that were to be taken. In the article, Rothbard writes of his vision of the state as an entity inherently hostile to society, permanently at odds with the individual and consistently in violation of the non-aggression principle. He views the contemporary US as an alliance of Big Government, big business and numerous special interest groups. The old America, characterized by a small government, respect for individual freedom and property rights was replaced by a throwback to a more distant past - European past. Rothbard sees a new alliance of the throne and the altar in political and business elites teaming up with intellectuals, defenders of the status quo, priests of the state. ${ }^{30}$ What is new is the elaboration of tactical assumptions that would help to withdraw the state from at least some of its current spheres of activity. Rothbard says the tactics utilized hitherto were not effective, ${ }^{31}$ especially Hayek's idea of the metamorphosis of the intellectual elite, which, illuminated with the notion of liberty would become willing to change the modern realities to more liberal ones. Rothbard says this idea cannot work in practice as we cannot assume that the intellectual elite is at all interested in seeking the truth and that it is merely mistaken in its outlook. He argues, putting idealism aside, that belonging to the elite is simply beneficial in itself and praising the state is a method of securing a prosperous existence - at the cost of other people of course, but that, apparently, is a price that the "ideological bodyguards of the state" are willing to pay. That does not mean that libertarians should altogether cease all activities within the sphere ideas. Instead, they

\footnotetext{
${ }^{29}$ M. N. Rothbard, “A New Fusionism”, Rothbard-Rockwell Report, May 1990, p. 1.

${ }^{30}$ Idem, "Right-Wing Populism: a Strategy for the Paleo Movement", Rothbard-Rockwell Report, January 1992, p. 7.

${ }^{31}$ Rothbard also mentions other approaches, such as lobbying for libertarian solutions, or those that grant the people greater freedom, and the tactics of libertarians having a political party of their own. More on these alternative tactics can be found in: Ibidem, pp. 9-12.
} 
should abandon their attempts at convincing the existing elite, and attempt to build their own. This would ally them with paleoconservatives, who would like to see Old America returning. One could conclude that Old America, to them, is an idealized vision of the past, which they would like to resurrect. Each conservatism inherently idealizes bygone things and seeks a way to return to them. A paleolibertarian, such as Rothbard, would undoubtedly favor the idea a state that interferes little with the lives of citizens, a minimal state - Old America. But would he consider this a true promised land? For him, it would likely constitute a mere stage in the quest to privatize all property. Libertarians are idealists, but they idealize the future, no the past. The status quo they desire has never yet occurred. Their actions are supposed to bring it about. Even when they enter an alliance in which both parties have different opinions on whether the state should exist and in what form.

Rothbard thought that the state of his time drew its strength from the effort of productive citizens. He concluded, therefore, that the ones he needed to convince were those that were bankrolling the state: the middle class and the working class. The paleolibertarian elite - allied with the paleoconservative elite - would therefore have to expose the hypocrisy of the modern state on a concrete example: the US. Thus, the program of right-wing populism would have to focus on those areas, in which it is possible to liberate typical American - one whose work supports the elites that are hostile to him. What is interesting, in designing this program Rothbard didn't criticize the state as such, possibly for tactical reasons. He only attacked the elites that direct the state. What should be done to make the lives of Americans easier and return their freedom to them? Rothbard enumerates:

1. Slash taxes. Freeing citizen from financial strains as much as it is possible, particularly from the income tax which should be abolished first.

2. Slash welfare, or at least seriously limite the welfare state.

3. Abolish racial and group privileges.

4. Take Back the Streets: Crush Criminals. In Rothbard's view the police should have the right to punish murders, rapists and thieves on the spot.

5. Take Back the Streets: Get Rid of The Bums. Rothbard concludes this point with a rhetorical question: where will they go? Who cares? At the same time, he expresses hope that being tough on the homeless would force at least some of them seek gainful employment.

6. Abolish the FED, attack the banksters. Rothbard stipulates in his considerations on banking that a system that could replace the current one, is one without a central bank and the note-issuing privilege, where gold-backed money is produced privately.

7. America First. This is to be understood as a policy of not supporting poor countries (Rothbard uses the word "bum" here), curbing interventionism and a focus on domestic rather than global policy. 
8. Defend Family Values. This pertains to ending the state's interference in the family. This point also includes the privatization of education and handing control over it to local communities, for example neighborhood-based ones. ${ }^{32}$

Then, the "paleo movement" would have to focus on more than just increasing the quality of life of the state-supporting citizens, which the above points are intended to attain. It would also be necessary to change the way people think about the remaining parts of the state. The program of right-wing populism is not anarcho-capitalist in nature. It assumes the continued existence of the state, but in a very reduced form. The state would continue to own certain goods that would have to be managed well. Rothbard said that it was necessary to drop the approach of modal libertarians who consider every state-owned institution to be a cesspool, and would treat it as such. To the contrary: those assets that remain in the state's control (awaiting privatization, even though obviously not all would be privatized) must be managed effectively and as close to the market conditions as possible. They could also be passed to local communities. It would be necessary to change overall approach to the whole sphere of public services, where, Rothbard says, one needs to use common sense, when it comes to, for instance, the question of religion in schools or respecting basic constitutional values in public life. ${ }^{33}$

All matters deemed controversial by the "paleo alliance", such as pornography, prostitution, abortion and legalization of drugs, ${ }^{34}$ should be, in Rothbard's view, regulated on the local level. The priority here is to take power away from the central government and move it, if it still needs to be exercised, to lower a level of regulation, such as local structures.

The program of right-wing populism creates controversies that its libertarian, and paleolibertarian reader must deal with. Rothbard wrote:

So far: every one of these right-wing populist programs is totally consistent with a hard-core libertarian position. ${ }^{35}$

Which must be surprising, particularly when it comes to the point on increasing the competence of the police, which would in some cases render officers judge, jury and executioner. It is hard to call such a postulate libertarian. What could give us a clue to understand the entire program, is another quote from Rothbard, which comes immediately after the highly optimistic declaration quoted above:

\footnotetext{
${ }^{32}$ Ibidem, pp. 8-9.

${ }^{33}$ Ibidem, p. 9.

${ }^{34}$ These issues Rothbard put together under one common bander of "family values".

${ }^{35}$ Idem, Right-Wing Populism..., op. cit., p. 9.
} 
But all real-world politics is coalition politics, and there are other areas where libertarians might well compromise with heir paleo or traditionalist or other partners in a populist coalition. ${ }^{36}$

If right-wing populism is to be taken as a political response to the "here and now," so the US of the early 1990s, a proposition that would have to be accepted by more than one ideological environment, and which would be designed to appeal to a broad spectrum of voters - then, in contrast to Rothbard's claims, the "non-libertarianism" of a part of this program could be marginalized. Right-wing populism is a resultant of what could actually be put forth, what would be accepted. And it is strictly within Rothbard's logic, who proposed adherence to principles, but at the same time advocated changing the system wherever possible, even at the cost of (temporary) abandonment of a part of the program. Jubilation is also possible after a tactical victory that brings one closer to the final goal.

\section{Pat Buchanan and the presidential election of 1992}

Similar conclusion can be drawn from Rothbard's declaration of support for Pat Buchanan in the presidential race. This step was a logical consequence of previous ones. A culmination of activities that included:

1. The identification of libertarians' weakness in the sphere of politics.

2. Observing the dividing line within the libertarian movement and distinguishing two groups: the nihil-libertarians and the paleolibertarians, followed by persuading some libertarians to leave the movement.

3. The identification of an external ally in the paleoconservative movement.

4. Collaboration with that movement on the declarative level (political writing), the meta-ideological level (conferences, the John Randolph Club) and the program level (the idea for right-wing populism).

The fifth point was joining the campaign of one of the candidates for the Republican presidential nomination. Here, the previous forms of collaboration between paleolibertarians and paleoconservatives are visible again, and one dimension is added to the mix: the hard political area. Here Rothbard deals with the inertia of an inherited system in order to partially change its.

The reason paleolibertarians supported Pat Buchanan was not because he was the only suitable candidate, or even because he was close to them in ideological terms. ${ }^{37}$

\footnotetext{
${ }^{36}$ Ibidem, p. 9.

${ }^{37}$ Although he had to be well-known, seeing especially that he served as an adivsor to three US presidents Nixon, Ford and Reagan; he was also a political writer.
} 
Ron Paul was already active in politics at the time, and initially he did consider entering the race for the nomination; Rothbard, as the movement's ideologist would have welcomed his candidacy. ${ }^{38}$ However, Paul changed his mind after speaking with Buchanan and decided instead to support him. In jointly authored article titled "For President: Pat Buchanan" Rothbard and Rockwell explain Paul's decision in terms of political realism:

When Pat phoned him, without hesitation, Ron welcomed Pat's entry into the race, and pledged his support to the Buchanan effort. Unlike most libertarians, Ron Paul understands the real world of politics, and he realizes that in Pat Buchanan we have an unprecedented opportunity to forge a powerful paleo coalition, to create a new libertarian-conservative, Old Right movement that can grow, can became extraordinarily influential, and that can even take over the presidency within a short period of time. ${ }^{39}$

Rothbard explained his own support for Buchanan with realism. He saw Buchanan as the most acceptable presidential candidate, because there was no more need for a candidate to be a pure libertarian, a promoter of the idea. ${ }^{40}$ Buchanan had advantages that Rothbard described thus:

Pat Buchanan is our ideal candidate. He is highly intelligent; he is deeply principled; he is known and loved by millions of Americans; he has a great deal of experience in politics, though not in running for office. He is a superb public speaker; and his is personally a remarkable blend of reason and passion, which enables him to rouse the masses as no one else can do in our lifetime. He is a paleo through and through; he stands for America First, and for an older and finer America, an America of liberty and individual responsibility, of a culture permeated by sound religious values, and marked by a happy and optimistic view of mankind and of the universe. He speaks to the best in every American, and he has the capacity to get them to listen. $\mathrm{He}$ speaks the best hope for bringing sack that kind of America. ${ }^{41}$

Supporting him would allow for a return of the Old Right. Buchanan was something of an anachronism, a relic of another time:

\footnotetext{
${ }^{38}$ M. N. Rothbard, L. H. Rockwell Jr.; "Ron Paul for President!", Rothbard-Rockwell Report, November 1991, p. 10-12.

${ }^{39}$ Eidem: "For President: Pat Buchanan", Rothbard-Rockwell Report, January 1992, p. 1.

${ }^{40}$ M. N. Rothbard, "Pat Buchanan and His Critics", Rothbard-Rockwell Report, February 1992, p. 1.

${ }^{41}$ M. N. Rothbard, L. H. Rockwell Jr., For President: Pat Buchanan, op. cit., pp. 1, 4.
} 
Pat Buchanan is a man of the Old Culture, of a culture that seemed to have died abruptly in America sometime in the late 1960s; and this is one of the reasons many of us love him. ${ }^{42}$

Rothbard identified with the Old Right. He made a very interesting statement during his speech for the John Randolph club on January $18^{\text {th }} 1992$. It was later printed in the Rothbard-Rockwell Report. To the chagrin of left-wing libertarians, he said he was celebrating his return to the Right:

The second celebration is mine personally: my own return home to the Right-wing, after 35 years in the political wilderness. Like a 19th-century Romantic hero, I am confident that I am returning home at a higher level than when I departed. ${ }^{43}$

Of course, his support of Buchanan was not directed solely towards paleolibertarians. He also defended Buchanan to his opponents within the Republican Party. The accusations they made were typical of for the establishment and centered around attempt at discrediting Buchanan as a small-time politician or an anti-Semite. From the point of view of libertarianism, or its paleolibertarian faction, these contribute nothing to the reflection on the problems of political realism or the implementation of a given political tactic which should be employed by the libertarian movement. ${ }^{44}$

Pat Buchanan lost the Republican nomination. That left only George Bush, whom Rothbard eventually decided to support. ${ }^{45}$ Not because the considered him a good candidate, but simply because he thought him better than Bill Clinton and Ross Perot. Rothbard saw the matter a one of a choice between two stronger candidates:

"Four More Years?" Yes, yes, for consider the alternative. It's come down to Bush or Clinton, and there can be only one rational answer for the conservative, the paleolibertarian, or indeed for any sensible American. Four More Years! ${ }^{46}$

It is difficult to consider this expression of support as something important in that period of Rothbard's activity. All it shows was that he was capable of choosing what he thought was the lesser evil and did not see everything in black and white. At

\footnotetext{
${ }^{42}$ M. N. Rothbard, "Pat Buchanan and the Old Right", Rothbard-Rockwell Report, February 1992, p. 11

${ }^{43}$ Idem, "A Strategy for the Right", Rothbard-Rockwell Report, March 1992, p. 1.

${ }^{44}$ A good example of Buchanan's defense against mainstream groups is Rothbard's article - see: idem, "Anti-Buchanania: A Mini-Encyclopedia", Rothbard-Rockwell Report, May 1992, p.1. and pp. 5-13.

${ }^{45}$ Writing in the RRR, Rothbard also spoke warmly of Ross Perot, whom he saw as an honest self-made man. Eventually, however he withdraw his support for him.

${ }^{46}$ Idem, "Working Our Way Back to the President", Rothbard-Rockwell Report, September 1992, p. 1.
} 
the same time, he did not consider Bush a good candidate. He was just better than Clinton. Bush was very strong politically and the paleolibertarian support certainly did not hurt him, but could not help him either. Rothbard and his followers had too little influence to be significant. 